\title{
Taxonomic study of Hoplias microlepis (Günther, 1864), a trans-Andean species of trahiras (Ostariophysi: Characiformes: Erythrinidae)
}

\author{
George M. T. Mattox ${ }^{1}$, Alessandro G. Bifi ${ }^{2}$ and Osvaldo T. Oyakawa ${ }^{3}$
}

The Hoplias malabaricus species group represents one of the most complexes taxonomical problems in the systematics of Neotropical fishes, including specimens widely distributed in most drainages of South America and part of Central America with great variation or overlap of putative diagnostic characters. The large number of nominal species, many of which without known type material, renders the problem more complicated. Currently, at least three nominal species can be included in the Hoplias malabaricus species group based on the form of the medial margins of dentaries and presence of tooth plates on the tongue: Hoplias malabaricus, $H$. teres, and $H$. microlepis, the latter representing the only exclusively trans-Andean known species of the genus. We present herein a taxonomic study of Hoplias microlepis based on examination of syntypes and recently collected specimens, including a redescription of the species. Hoplias microlepis occurs in the Pacific drainages of Panama and Southwestern Costa Rica, in addition to the río Guayas basin in Ecuador and the region near its mouth (río Tumbes, Northwestern Peru). Records of the species on the Atlantic coast of Panama are restricted to the Canal Zone, suggesting dispersal through the Panama Canal. We also designate lectotype and paralectotypes.

O grupo de espécies Hoplias malabaricus representa um dos problemas taxonômicos mais complexos na sistemática de peixes Neotropicais, com ampla distribuição em quase todas as bacias da América do Sul e parte da América Central e grande variação ou sobreposição de prováveis caracteres diagnósticos. O grande número de espécies nominais, muitas delas sem material-tipo conhecido, é um fator complicador nessa questão. Atualmente, pelo menos três espécies nominais podem ser incluídas no grupo de espécies Hoplias malabaricus, com base no formato das margens mediais dos dentários e presença de dentes na língua: Hoplias malabaricus, H. teres e H. microlepis, a última sendo a única espécie exclusivamente trans-andina do gênero conhecida até o momento. Apresentamos aqui um estudo taxonômico de Hoplias microlepis, com exame dos síntipos e exemplares coletados mais recentemente, incluindo uma redescrição da espécie. Hoplias microlepis distribui-se nas bacias da costa Pacífica do Panamá e sudoeste da Costa Rica, além da bacia do río Guayas no Equador e região próxima à sua foz (río Tumbes, noroeste do Peru). Registros da espécie na costa Atlântica do Panamá são restritos à Zona do Canal, sugerindo dispersão através do Canal do Panamá. São designados também lectótipo e paralectótipos.

Key words: Central America, Hoplias malabaricus species group, Taxonomy, Trans-Andean distribution, Wolf fish.

\section{Introduction}

The Erythrinidae is a Neotropical characiform family comprising three extant genera, Erythrinus Scopoli, Hoplerythrinus Gill, and Hoplias Gill, the latter constituting the most speciose of the three (Oyakawa, 2003). Oyakawa (1990) and Oyakawa \& Mattox (2009) defined three groups within Hoplias: the H. macrophthalmus group which comprises a single valid species, H. aimara (Valenciennes) (see Mattox et al., 2006), the H. lacerdae group currently including five valid species (H. australis Oyakawa \& Mattox, $H$. brasiliensis (Spix), H. curupira Oyakawa \& Mattox, $H$. intermedius (Günther) and H. lacerdae Miranda-Ribeiro, see Oyakawa \& Mattox, 2009) and the H. malabaricus group, still lacking a proper taxonomic approach. Contrary to what was mentioned by Blanco et al. (2010), H. aimara is not included in the H. lacerdae group, but rather assigned to the H. macrophthalmus group (see Mattox et al., 2006; Oyakawa

\footnotetext{
${ }^{1}$ Departamento de Biologia, Universidade Federal de São Carlos - câmpus Sorocaba. Rodovia João Leme dos Santos (SP-264), km 110, Bairro do Itinga, 18052-780 Sorocaba, SP, Brazil.gmattox@ufscar.br

${ }^{2}$ Núcleo de Pesquisas em Limnologia Ictiologia e Aquicultura, Universidade Estadual de Maringá. Av. Colombo, 5790, 87020-900 Maringá, PR, Brazil.agbifi@hotmail.com

${ }^{3}$ Museu de Zoologia da Universidade de São Paulo, Caixa Postal 42494, 04218-970 São Paulo, SP, Brazil. oyakawa@usp.br
} 
$\&$ Mattox, 2009). This error has been repeated by subsequent authors (e.g., Blanco et al., 2011; Cioffi et al., 2012; Marques et al., 2013). Similarly, H. microlepis (Günther) and H. teres (Valenciennes) were not included in the H. lacerdae group as stated by Marques et al. (2013), but rather belong to the $H$. malabaricus group (see below).

Hoplias malabaricus (Bloch) represents perhaps one of the most complex problems in the taxonomy of Neotropical fishes. This species is widespread in South America (e.g., Géry, 1977) occurring in drainages of both sides of the Andes. Meristic and morphometric data of specimens greatly overlap throughout the distribution range of the species (e.g., Bifi, 2013), and there is a large number of nominal species currently considered junior synonyms (e.g., Oyakawa, 2003), many of which without known type material. In addition, numerous cytogenetic studies have suggested that $H$. malabaricus represents a species complex (e.g., Bertollo et al., 1986; Dergam \& Bertollo, 1990; Bertollo et al., 1997; 2000; Born \& Bertollo, 2001; 2006; Cioffi et al., 2009a, 2009b; Rosa et al., 2009; Santos et al., 2009; Blanco et al., 2010; 2011; Cioffi \& Bertollo, 2010; Cioffi et al., 2011a, 2011b, 2011c, 2011d, in press; Marques et al., 2013).

The Hoplias malabaricus species group was defined by Oyakawa (1990) and Oyakawa \& Mattox (2009) to include species with the dentaries abruptly converging towards the mandibular symphysis and with tooth plates on the tongue. Based on these characters, at least two nominal species of Hoplias can be assigned to the group in addition to $H$. malabaricus: $H$. microlepis, and $H$. teres, the former having a trans-Andean distribution and the latter known from Lago Maracaibo, Venezuela. As an initial attempt to address the taxonomic complexity of the $H$. malabaricus species group, in the present study we present a redescription of $H$. microlepis, designate lectotype and paralectotypes, and estimate the geographic distribution of the species.

\section{Material and Methods}

This study was based on meristic and morphometric data from 64 specimens, including seven syntypes. Meristic data were taken under a stereomicroscope and the morphometric data were taken point-to-point with a digital caliper to 0.1 $\mathrm{mm}$. Measurements and counts were made on the left side of the body, whenever possible, and follow Fink \& Weitzman (1974) and Mattox et al. (2006). Unbranched and branched fin-ray counts are presented as Roman and Arabic numbers, respectively. Vertebral counts were made on radiographed specimens and include the anterior four vertebrae of the Weberian apparatus. The asterisk in the meristic characters refers to values of the lectotype. Osteological names follow Weitzman (1962) and Roberts (1969). Descriptions of coloration were based on specimens preserved in ethanol. Institutional abbreviations follow Ferraris Jr. (2007).

\section{Results}

\section{Hoplias microlepis (Günther, 1864) Figs. 1-3}

Macrodon microlepis Günther, 1864: 282 [original description; type-locality: Western Ecuador and Chagres River]. -Eigenmann \& Eigenmann, 1889: 102 [diagnosis in key, citation to Western slopes of South America from Guayaquil to Panama].

Macrodon trahira var. microlepis Steindachner, 1880: 101 [citation to Guayaquil, Ecuador].

Hoplias microlepis. -Starks, 1906: 772 [comparison with Hoplias malabaricus, citation to Guayaquil, Ecuador]. -Regan, 1908: 167 [redescription, citation to Rio Chagres, Panama and Western Ecuador]. -Meek \& Hildebrand, 1916: 303 [diagnosis in key, citation to both slopes of Panama and the Western slope of Ecuador]. -Eigenmann, 1921: 508-511 [citation, distribution]. -Eigenmann, 1922: 169 [diagnosis in key, citation to Pacific slope of Southern Ecuador and both slopes of Central Panama]. -Hildebrand, 1938: 290 [distribution]. -Bussing, 1966: 218 [citation to Puntarenas, Costa Rica]. -Géry, 1977: 102 [diagnosis in key, citation to Pacific slope of Southern Ecuador, Panama and Costa Rica]. -Ortega \& Vari, 1986: 10 [checklist, citation to Peru]. -Oyakawa, 2003: 240 [checklist, distribution]. -Barriga, 1991: 31 [checklist]. -Ortega et al., 2011: 39 [checklist, citation to Peru]. -Barriga, 2012a: 110 [distribution, endemism in Guayas basin]. -Barriga, 2012b: 213 [citation to Ecuador with photograph]. -Aguirre et al., 2013 [morphological and genetic divergence among populations in Ecuador].

Lectotype. Panama. Panama Province. Chagres basin: BMNH 1864.1.26.221, 269.7 mm SL, Chagres River, purchased of Mr. Salvin (Fig. 1) [designated herein].

Paralectotypes. Ecuador. BMNH.1860.6.16.128, 1, 276.6 mm SL, West Ecuador, collector Fraser; BMNH.1860.6.16.154-155, 3, 96.6$118.5 \mathrm{~mm}$ SL, West Ecuador, collector Fraser; Panama. Panama Province. Chagres basin: BMNH 1864.1.26. 222, 1, 222.8 mm SL, same information as lectotype; BMNH 1864.1.26.309, 1, $175.6 \mathrm{~mm}$ SL, same locality as lectotype, collected by Messrs. Dow \& Salvins (Fig. 2). [all designated herein].

Material examined. Ecuador. Guayas. Río Daule basin: BMNH 1898.11.4.45, 1, 230.9 mm SL, río Daule, West Ecuador, Dr. H. Festa; BMNH 1920.12.20.129-130, 2, 207.9-254.1 mm SL, Colimes, C. H. Eigenmann; BMNH 1920.12.30.131-132, 2, 174.1-188.9 mm SL, Guayaquil, C. H. Eigenmann; FMNH 93480, 5, 60.5-126.3 mm SL (5 specimens radiographed), Los Ríos, Río Palenque, Estación Biológica Río Palenque, about 5 miles downstream from station in an isolated pool, G. S. Glodek, G. Whitmire \& J. Dryan, 30 Jul 1974; USNM 53512, 2, 217.5-219.5 mm SL, Guayaquil, P. Simmons; USNM 94064, 6, 234.6-296.4 mm SL, Guayaquil, W. L. Schimitt, 05 Jan 1934; Panama. Chiriqui. USNM 78601, 1, 252.8 mm SL, Bas Obispo, Mandingo River, S. E. Meek \& S. F. Hildebrand, 02 Feb 1911; Coclé. USNM 310650, 1, 85.3 mm SL, Membrillal River at bridge on IAH (Inter-American Highway), about 5 miles East of Divisa, H. Loftin et al., 25 Feb 1962; USNM 310676, 1, $140.7 \mathrm{~mm}$ SL, creek about 3 miles West of Hato River at bridge on IAH (Inter-American Highway), H. Loftin \& E. Tyson, 14 Oct 1961; Colón. USNM 78606, 2, 131.2-141.5 mm SL, small creek at 
Mindi, S. E. Meek \& S. F. Hildebrand, 21 Jan 1911; USNM 78608 , 10, 55.7-108.9 mm SL, Gatún River, Canal Zone, S. E. Meek \& S. F. Hildebrand, 24 Jan 1911; USNM 78609, 4, 128.3-182.3 mm SL (4 specimens radiographed), creek opposite Mindi Cut, S. E. Meek \& S. F. Hildebrand, 17 Jan 1911; USNM 78613, 2, 143.2-156.9 mm SL (2 specimens radiographed), Mindi creek, French Cut-Off, Canal Zone, S. E. Meek \& S. F. Hildebrand, 2 Mar 1911; USNM 78614, 4, 106.5-137.9 mm SL, Gatún River, Monte Lirio, Canal Zone, S. E. Meek \& S. F. Hildebrand, 27 Mar 1911; USNM 78615, 4, 143.2$156.9 \mathrm{~mm}$ SL (4 specimens radiographed), Largateria Creek, Canal Zone, S. E. Meek \& S. F. Hildebrand, 09 Mar 1911; USNM 78617, 11, 143.2-156.9 mm SL (9 specimens radiographed), Mindi Creek, Canal Zone, S. E. Meek \& S. F. Hildebrand, 14 Jan 1911; USNM 310672, 1, $79.6 \mathrm{~mm}$ SL, Agua Salud creek on pipeline road near Gamboa, H. Loftin, et al., 31 Dec 1961; Darién. USNM 293250, 5, 164.7-176.2 mm SL (5 specimens radiographed), Pirre River, Tuira, above E1 Real, $8^{\circ} 05^{\prime} 60^{\prime \prime N} 77^{\circ} 45^{\prime} 00^{\prime}$ 'W, J. Lundberg, B. Chernoff \& L. Mcdade, 16 Feb 1985; Herrera. USNM 310444, 1, 186.7 mm SL (1 specimen radiographed), Barrera near Pesé, H. Loftin \& E. Tyson, 1961; USNM 310678, 1, 130.4 mm SL, Herrera Creek about 4 miles up Pesé road from junction with Chitre-Divisa Road, H. Loftin \& E. Tyson, 21 Oct 1961; Los Santos. USNM 78595, 3, 131.1-163.7 mm SL, río Abajo, S. E. Meek \& S. F. Hildebrand, 22 Apr 1911; Panama Province. USNM 78603, 2, 37.8-186.3 mm SL (2 specimens radiographed), Juan Diaz River, S. E. Meek \& S. F. Hildebrand, 17 Jul 1911; USNM 78605, 11, 37.8-186.3 mm SL (6 specimens radiographed), Alhajuela, Limon Creek, S. E. Meek \& S. F. Hildebrand, 26 Feb 1911; USNM 78607, 1, 138.1 mm SL, río Chagres, Gorgona, S. E. Meek \& S. F. Hildebrand, 01 Apr 1912; USNM 109278, 3, 35.4-153.4 mm SL, small creek tributary to Chagres River, Madden Dam Road, S. E. Hildebrand, 14 Feb 1935; USNM 310673, 1, $129.9 \mathrm{~mm}$ SL, creek at bridge on IAH (InterAmerican Highway), about 4 miles East of Pacora X-Road, G. H. Loftin \& M. Smith, 24 Apr 1962; Veraguas. MZUSP 47931, 2, 45.3-106.0 mm SL, creek at bridge about 9 miles from Santiago on San Francisco Road, H. G. Loftin, 14 Jan 1962; MZUSP 47932, 1, 132.7 mm SL, río Frijoles, S. E. Meek \& S. F. Hildebrand, 14 Mar 1911; USNM 78597, 1, 151.6 mm SL, Trinidad River, Icc. Hydro Station, S. E. Meek \& S. F. Hildebrand, 08 Mar 1911; USNM 78598 , 2, 134.4-138.7 mm SL, Gatun, Trinidad River, S. E. Meek \& S. F. Hildebrand, 24 Jan 1911; USNM 78599, 2, 116.1-144.7 mm SL, Agua Clara, Trinidad River, S. E. Meek \& S. F. Hildebrand, 10 Mar 1911; USNM 78600, 1, 148.5 mm SL, Agua Clara, Trinidad River, Canal Zone, S. E. Meek \& S. F. Hildebrand, 10 Mar 1911; USNM 78611, 5, 32.3-138.2 mm SL, Frijoles River, Canal Zone, S. E. Meek \& S.
F. Hildebrand, 13 Feb 1911; USNM 78612, 1, 98.5 mm SL, Gorgona Reservoir, Canal Zone, S. E. Meek \& S. F. Hildebrand, 28 Mar 1912; USNM 310677, 1, 70.2 mm SL, creek 13 miles West of Ocu X-road, Loftin, et al., 21 Oct 1961; USNM 310680, 1, 189.4 mm SL, creek 20 miles West of Santiago, H. Loftin, 1961.

Diagnosis. Hoplias microlepis differs from all other species of Hoplias, except for species of $H$. malabaricus group, in the shape of the dentaries abruptly converging towards the mandibular symphysis (Oyakawa \& Mattox, 2009: 118, Fig. 1d) (vs. dentaries parallel and only gently converging towards the mandibular symphysis) and by the presence of tooth plates on tongue (vs. tooth plates on tongue absent). H. microlepis is also distinguished from $H$. brasiliensis and $H$. curupira in the number of scales along lateral line (43-47 vs. 38-43 and 34-39, respectively), and from $H$. australis and $H$. lacerdae in the number of pores of the laterosensory system along the ventral surface of dentary (4 vs. always 5 and 6-8 respectively). $H$. microlepis is distinguished from $H$. aimara by the presence of the accessory ectopterygoid and lack of a vertically elongate dark spot on the opercular membrane (vs. accessory ectopterygoid absent and dark spot present). $H$. microlepis is distinguished from the other species in the $H$. malabaricus species group by the higher number of scales around the caudal peduncle (22-24, usually 24 vs. 18-20, usually 20).

Description. Morphometric data presented in Table 1. Body cylindrical, deeper than wide. Greatest body depth at vertical through fifth or sixth scale anterior to dorsal-fin origin in specimens smaller than $61.4 \mathrm{~mm} \mathrm{SL}$, closer to dorsal-fin origin in larger specimens. Anterior profile of head angular in lateral view. Overall dorsal profile of head straight, slightly convex anteriorly towards snout. Dorsal margin of orbit located at horizontal through dorsal profile of head in specimens smaller than $45.3 \mathrm{~mm}$ SL, but not reaching dorsal profile of head in larger specimens (ca. $61.4 \mathrm{~mm} \mathrm{SL}$ ). Dorsal profile of trunk slightly convex from vertical through first series of scales of body to dorsal-fin origin; straight and

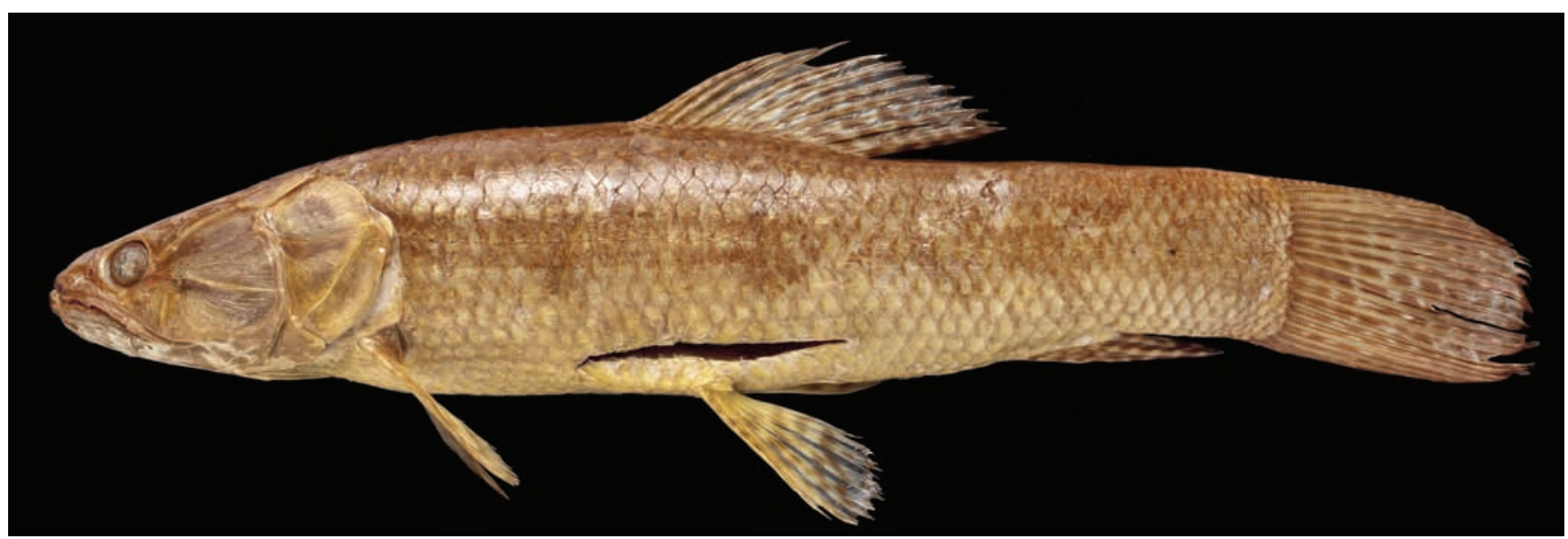

Fig. 1. Hoplias microlepis (lectotype of Macrodon microlepis), BMNH 1864.1.26.221, 269.7 mm SL, Chagres River, Panama. 


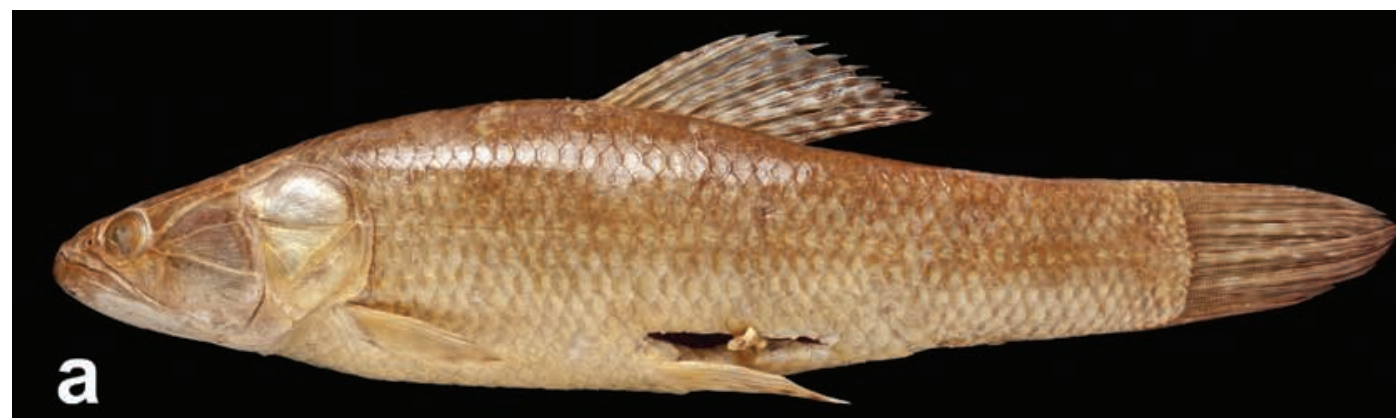

b
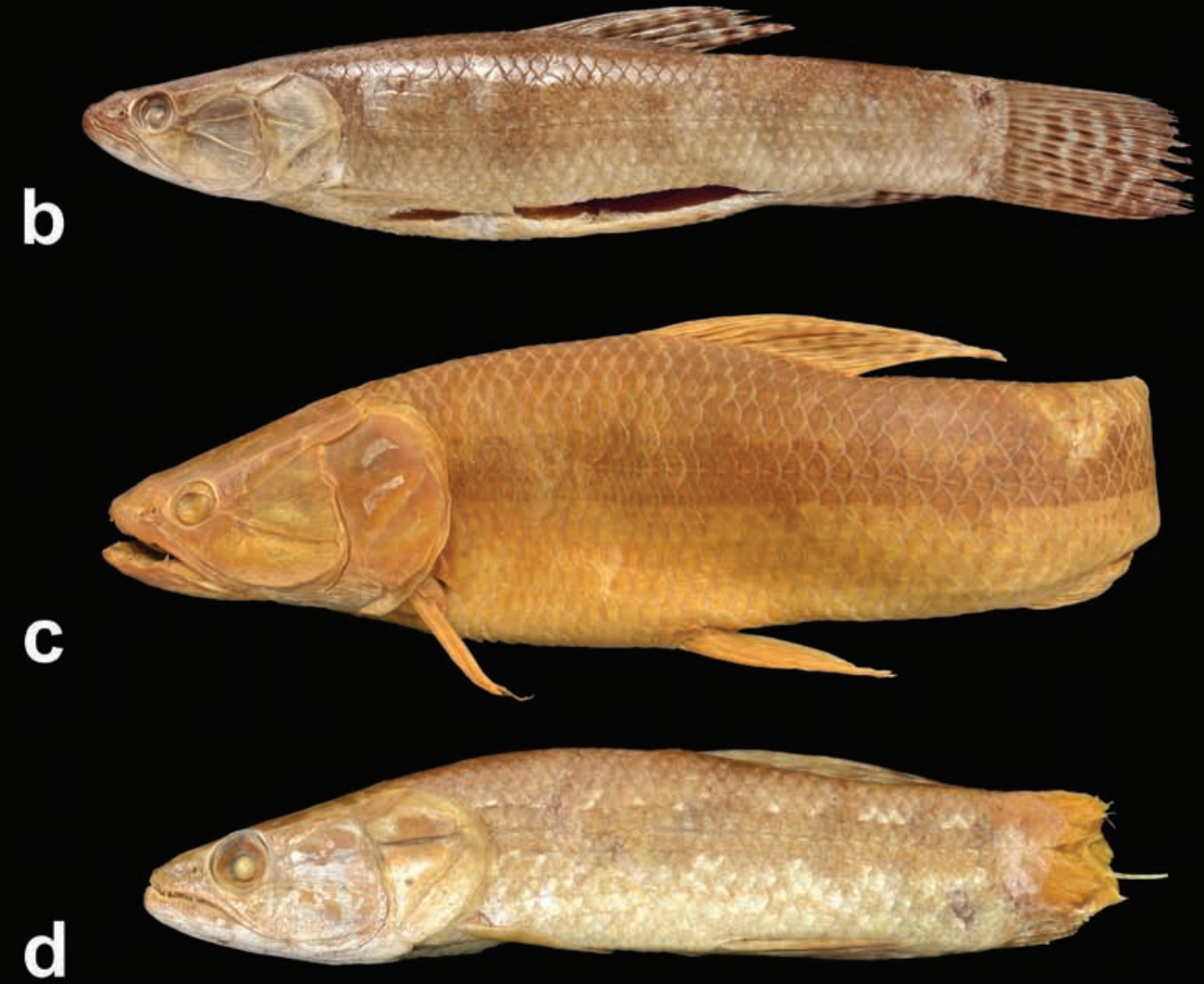

d

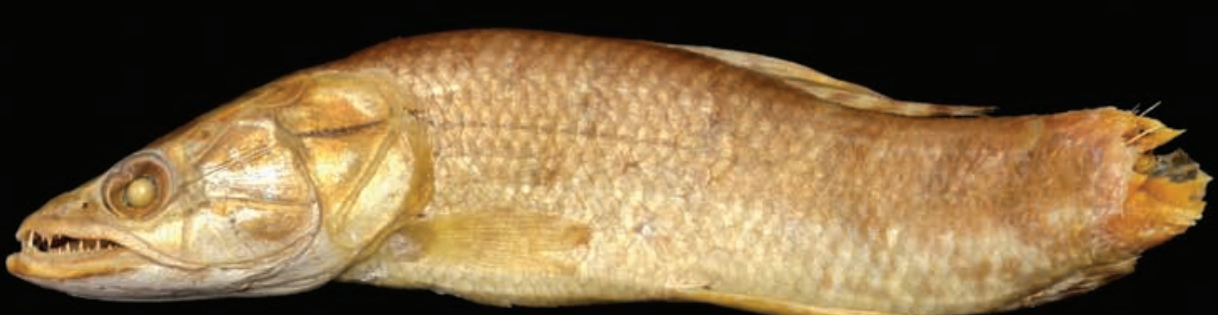

e

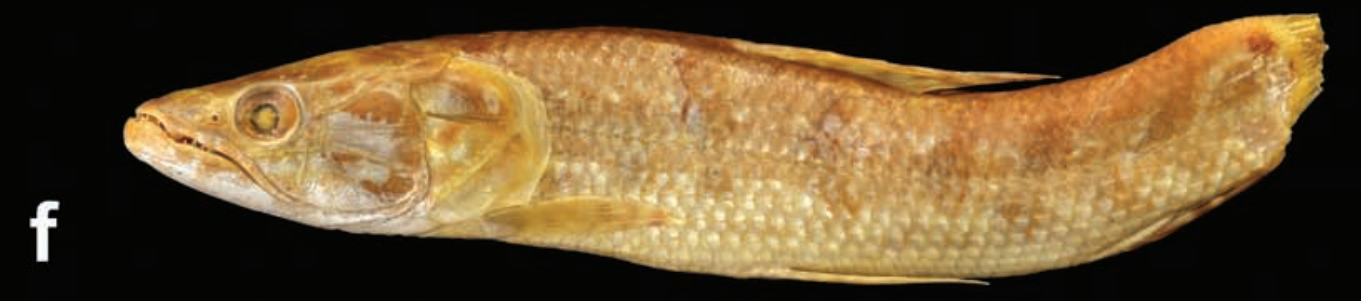

Fig. 2. Hoplias microlepis (paralectotypes of Macrodon microlepis). (a) BMNH 1864.1.26.222, $222.8 \mathrm{~mm}$ SL, Chagres River, Panama; (b) BMNH 1864.1.26.309, 175.6 mm SL, Chagres River, Panama; (c) BMNH 1860.6.16.128, 276.6 mm SL, West Ecuador; (d) BMNH 1860.6.16.154-155, 96.6 mm SL, West Ecuador; (e) BMNH 1860.6.16.154-155, 108.2 mm SL, West Ecuador; (f) BMNH 1860.6.16.154-155, 118.5 mm SL, West Ecuador. 
posteroventrally inclined along dorsal-fin base; straight and less inclined to slightly concave from vertical through base of last dorsal-fin ray to origin of anteriormost dorsal procurrent caudal-fin ray. Ventral profile of lower jaw distinctly angular in region of mandibular symphysis, straight to slightly inclined from vertical through anterior nostril to posterior margin of lower jaw. Medial margins of contralateral dentaries abruptly converging anteriorly towards symphysis. Ventral profile of trunk slightly convex to pelvic-fin origin; approximately straight to slightly convex from latter point to anal-fin origin; straight and posterodorsally inclined along anal-fin base; straight or slightly concave from base of last anal-fin ray to anteriormost ventral procurrent caudal-fin ray.

Upper jaw slightly shorter than lower jaw. Posterior portion of maxilla dorsally enlarged and extending medially to anterior margins of second and third infraorbitals. Upper and lower lips fleshy, with short projections of skin covering canines externally. Anterior nostril tubular with anterior slit reaching base of tubular portion. Anterior and posterior nostrils situated along horizontal through center of orbit, posterior nostril situated midway between anterior nostril and anterior margin of orbit. Eye proportionately larger in smaller specimens. Infraorbital bones well developed and horizontally elongate. Infraorbitals 3,4 , and ventral portion of 5 partially covering preopercle. Anteroventral margin of infraorbital 3 relatively straight and posteroventral margin convex. Posterior margin of infraorbitals 4,5 , and 6 slightly convex.

Teeth in both jaws conical or canine. Premaxillary teeth in single row. First premaxillary tooth large canine, second tooth medium sized canines. Seventh tooth canine almost as large as anterior most premaxillary canine. Third to sixth, and eighth premaxillary teeth small and conical. Maxilla with single row of approximately 38-39 relatively small teeth, except for very welldeveloped canine-like fourth or fifth tooth. Dentary with anterior external row of teeth and posterior internal row. External series with four anterior small teeth, followed by two well-developed canines with posterior canine larger than anterior canine, and then 11 conical teeth slightly smaller than anterior most dentary canine. Internal series beginning immediately posterior to last conical tooth of external row and composed of approximately 15 very small teeth. Accessory ectopterygoid and ectopterygoid toothed. Ectopterygoid with series of small conical teeth along ventrolateral margin and many smaller viliform teeth on ventromedial surface. Endopterygoid edentulous.

Distal margins of all fins rounded. Dorsal-fin rays ii, 11-13 (mode: ii, $12^{*}, \mathrm{n}=64$ ). Dorsal fin located at midbody, its origin at vertical through approximately fourth scale anterior to series along pelvic-fin origin. Longest dorsal-fin ray approximately three-quarters of body depth. Anal-fin base short. Anal-fin rays iiiii, 7-9 (mode: ii, $8^{*}, n=61$ ). Tip of depressed dorsal fin reaching vertical through anal-fin origin in small specimens (less than $138 \mathrm{~mm} \mathrm{SL}$ ) but falling short of that point in larger specimens. Pectoral-fin rays i,10-14 (mode: i,13, $\mathrm{n}=63$, lectotype with i,12). Pectoral-fin origin located at about vertical through median region of opercle. Tip of pectoral fin separated from pelvic-fin origin by three to five scales. Pectoral and pelvic fins of similar size. Pelvic-fin rays i,7* $(n=64)$. Pelvic-fin origin situated at midbody and approximately four scales posterior to vertical through dorsal-fin origin. Tip of pelvic fin separated from analfin origin by five or six scales. Caudal-fin rays i,15, $i^{*}(n=58)$.

Table 1. Morphometric data of Hoplias microlepis. Standard length in mm; values 1-14 are percentages of the standard length and values 15-22 are percentages of head length. $\mathrm{n}=$ number of examined specimens, $\mathrm{SD}=$ standard deviation.

\begin{tabular}{|c|c|c|c|c|c|c|c|c|c|}
\hline & \multirow{2}{*}{ Lectotype } & \multicolumn{4}{|c|}{ Paralectotypes } & \multicolumn{4}{|c|}{ Non-type material } \\
\hline & & $\mathrm{n}$ & Mean & Range & SD & $\mathrm{n}$ & Mean & Range & SD \\
\hline Standard length & 269.7 & 6 & - & $96.6-276.6$ & - & 57 & - & $35.4-296.4$ & - \\
\hline 1. Body depth & 20.5 & 6 & 22.2 & $20.0-28.4$ & 3.4 & 54 & 22.1 & $15.9-26.5$ & 2.3 \\
\hline 2. Head length & 30.2 & 6 & 33.1 & $29.8-36.1$ & 2.7 & 57 & 31.8 & $29.0-36.7$ & 1.5 \\
\hline 3. Pectoral-fin length & 17.1 & 6 & 18.0 & $16.9-19.7$ & 0.9 & 56 & 18.1 & $15.7-20.2$ & 0.9 \\
\hline 4. Pelvic-fin length & 18.3 & 6 & 20.1 & 18.4-21.6 & 1.5 & 57 & 19.7 & $17.8-21.8$ & 0.9 \\
\hline 5. Anal-fin length & 18.0 & 3 & 18.8 & $18.0-19.3$ & 0.7 & 57 & 19.3 & $16.8-22.8$ & 1.1 \\
\hline 6. Dorsal-fin length & 31.5 & 6 & 31.7 & $29.8-34.1$ & 1.6 & 56 & 30.8 & $28.1-34.2$ & 1.3 \\
\hline 7. Dorsal-fin base & 20.2 & 6 & 19.5 & $18.6-20.7$ & 0.8 & 57 & 18.5 & $16.5-20.1$ & 0.8 \\
\hline 8. Anal-fin base & 9.1 & 3 & 9.7 & $9.5-10.0$ & 0.2 & 57 & 9.8 & $8.0-11.8$ & 0.7 \\
\hline 9. Pre-pectoral distance & 28.3 & 6 & 30.5 & $27.0-33.3$ & 2.4 & 57 & 29.1 & $26.1-37.1$ & 1.7 \\
\hline 10. Pre-pelvic distance & 53.0 & 6 & 54.3 & $50.2-56.8$ & 2.6 & 55 & 54.8 & $50.5-58.7$ & 1.9 \\
\hline 11. Pre-dorsal distance & 48.1 & 6 & 52.5 & $47.3-56.1$ & 3.4 & 57 & 50.5 & $46.2-57.8$ & 2.1 \\
\hline 12. Pre-anal distance & 79.7 & 5 & 82.9 & $75.8-85.9$ & 4.1 & 57 & 81.2 & $77.0-84.7$ & 1.8 \\
\hline 13. Caudal-peduncle depth & 12.6 & 6 & 13.8 & $12.2-15.5$ & 1.2 & 57 & 13.6 & $11.5-15.8$ & 0.9 \\
\hline 14. Caudal-peduncle length & 15.2 & 3 & 14.7 & $14.3-15.4$ & 0.6 & 17 & 14.5 & $12.4-16.0$ & 1.0 \\
\hline 15. Head depth & 45.2 & 6 & 45.2 & $41.8-48.4$ & 2.5 & 57 & 50.7 & $43.2-57.3$ & 3.4 \\
\hline 16. Snout length & 24.7 & 6 & 25.4 & $24.6-26.0$ & 0.5 & 57 & 24.7 & $21.5-26.8$ & 1.0 \\
\hline 17. Snout width & 25.0 & 6 & 22.5 & $20.0-26.5$ & 2.4 & 57 & 23.0 & $18.4-26.1$ & 1.4 \\
\hline 18. Snout depth & - & - & - & - & - & 40 & 26.0 & 22.9-29.2 & 1.6 \\
\hline 19. Pre-nasal distance & 16.3 & 6 & 14.6 & 11.7-16.1 & 1.5 & 56 & 15.7 & $13.4-22.9$ & 1.6 \\
\hline 20. Orbital diameter & 15.1 & 6 & 16.1 & 12.9-17.6 & 1.7 & 57 & 18.5 & $14.1-27.6$ & 2.4 \\
\hline 21. Interorbital width & 29.1 & 6 & 25.9 & 23.8-28.2 & 1.8 & 57 & 26.1 & $21.6-30.1$ & 1.8 \\
\hline 22. Upper jaw length & 54.8 & 6 & 49.4 & $47.5-51.1$ & 1.5 & 57 & 51.6 & $48.3-56.6$ & 1.5 \\
\hline
\end{tabular}


Well-developed cycloid scales imbricated along body. Series of dorsal scales beginning at vertical on posterior margin of parietals and overlapping supraoccipital spine. Last vertical series of scales on caudal peduncle forming straight vertical line on caudal-fin base in lateral view. Anterior margin of scales with small concavity and posterior margin rounded. Approximately twelve radii extending from center of scale to its anterior margin and around sixteen radii, some anastomosed, extending from center of scale to its dorsal, posterior, and ventral margins. Lateral line straight and complete, extending from posteroventral margin of supracleithrum to posteriormost scale on body. Lateral line with 43-47 (mode: $45, \mathrm{n}=61$, lectotype with 44 ) scales. Longitudinal series of scales between lateral line and dorsalfin origin 6.5-7.5 (mode: $6.5^{*}, \mathrm{n}=63$ ). Longitudinal series of scales between lateral line and pelvic-fin origin 5.5-6.5 (mode: $5.5^{*}, \mathrm{n}=63$ ). Longitudinal series of scales around caudal peduncle 22-24 (mode: $24^{*}, \mathrm{n}=62$ ).

Approximately 9 gill rakers on first epibranchial, most in form of small denticulated plates. Lower branch of first branchial arch with 4-6 (mode: $5^{*}, \mathrm{n}=48$ ) more elongate rakers and approximately 10 plate-like rakers. Laterosensory canal along ventral surface of dentary with $4 *(n=61)$ pores, one specimen with 5 pores. Total vertebrae: $42-45(n=41)$, 28-30 precaudal and 13-15 caudal vertebrae.

Color in alcohol. Ground coloration of head and body dark to light brown, darker dorsally and paler ventrally (Fig. 3). Ventral region homogeneously white or light yellow in specimens up to $106.2 \mathrm{~mm}$ SL. Larger specimens (i.e., $130.0 \mathrm{~mm} \mathrm{SL}$ ) with scales of ventrolateral surface of body with white central portion bordered by darker pigmentation, giving aspect of thin longitudinal dark and pale stripes. Specimens up to $60 \mathrm{~mm} \mathrm{SL}$ with conspicuous dark longitudinal stripe along lateral line scales, covering approximately half of the series immediately above and below lateral line. Longitudinal dark stripe less conspicuous in larger specimens. Approximately five to six darker parallel diagonal bars along dorsal region extending anteroventrally to just below lateral line (Fig. 3). Diagonal dark bars in many specimens continuing posteroventrally to approximately three longitudinal scale series below lateral line, resulting in chevronlike pattern. Dorsal portions of bars more evident than ventral portions. Bars more conspicuous in specimens with light brown ground coloration. Specimens larger than $106.0 \mathrm{~mm}$ SL with conspicuous round spot on dorsal portion of caudal peduncle, near base of uppermost caudal-fin rays (Fig. 3). Dorsal surface of head dark brown. Lips with alternating dark and light vertical bands, inconspicuous in some specimens. Ventral surface of dentaries varying from white in small specimens (ca. $35.4 \mathrm{~mm} \mathrm{SL}$ ), to alternating dark and light transverse stripes in specimens larger than $61.4 \mathrm{~mm}$ SL. Coloration of infraorbital region and dorsal surface of head similar to each other. Many specimens with two dark stripes radiating posteriorly from eye along infraorbital 6 and dorsal portion of infraorbital 3. Ground coloration of opercular series dark brown. Opercular membrane usually lighter than opercle (Fig. 3).

All fins light brown, lighter than body in some specimens, with dark spots on rays and interradial membranes forming pattern of irregular dark stripes (Figs. 1, 2a-b, 3). Stripes on pelvic, anal and caudal fins wider and more regular than those on dorsal fin. Ventral surfaces of pectoral and pelvic fins either lighter than, or with same pattern as, dorsal surface, but with pattern less conspicuous. Fins of largest specimens (ca. 163.0 $\mathrm{mm} \mathrm{SL}$ ) usually darker than rest of body.

Distribution. Hoplias microlepis occurs in rivers along the entire Pacific coast of Panama and in rivers tributaries to the Panama Canal including the Atlantic coast. The species also occurs in the río Guayas basin which empties in the Gulf of Guayaquil, Ecuador. Although we did not examine specimens from Costa Rica and Peru, there are records in the literature of Hoplias microlepis in Puntarenas, Southwestern Costa Rica (Bussing, 1966) and río Tumbes, Northwestern Peru (Ortega \& Vari, 1986) (Fig. 4).

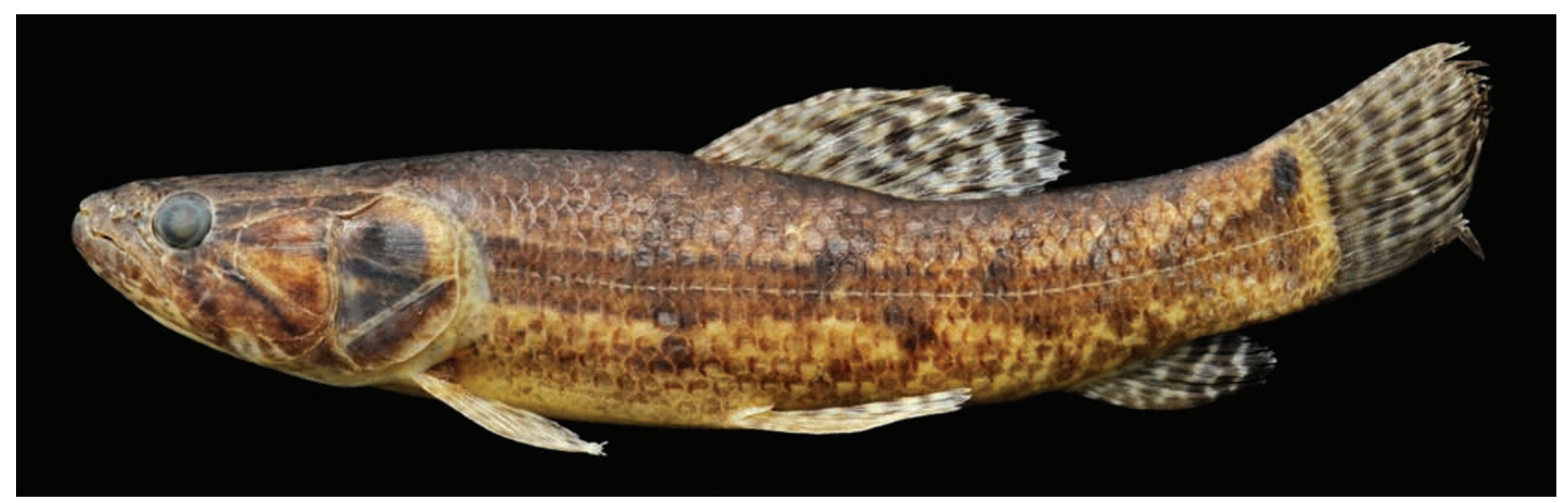

Fig. 3. Hoplias microlepis, USNM 293250, 176.2 mm SL, Pirre River, Tuira, Panama. 


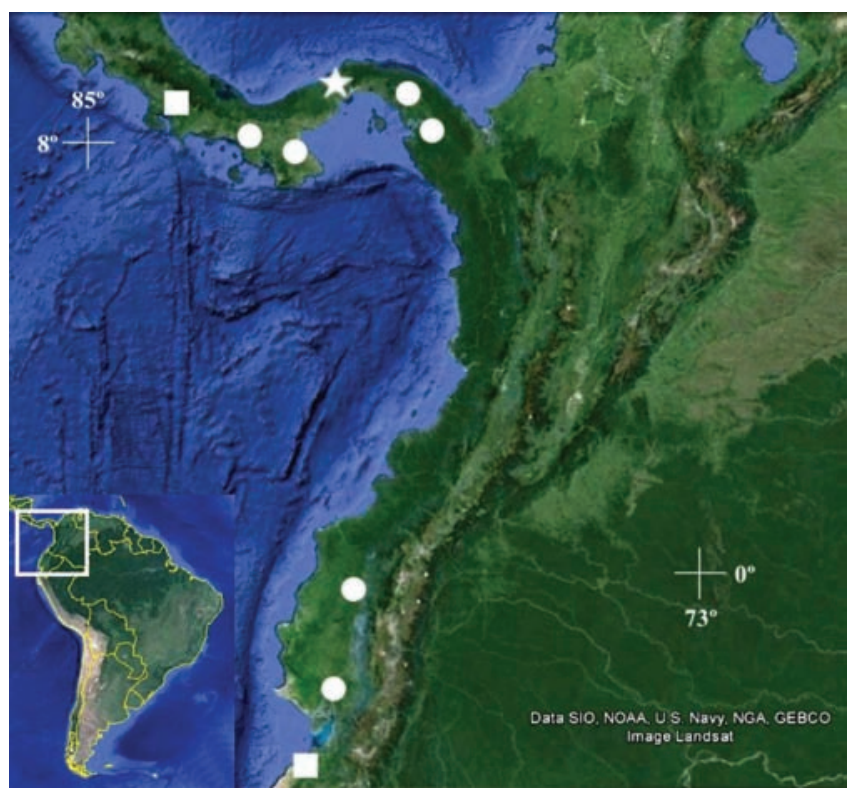

Fig. 4. Map of Northwestern South America and part of Central America showing geographic distribution of Hoplias microlepis based on material examined herein (star and dots) and records from literature (squares). Star indicates type-locality at Chagres River, Panama. Some symbols may represent more than one lot.

\section{Discussion}

The Hoplias malabaricus species group was defined by Oyakawa (1990) and Oyakawa \& Mattox (2009) to include specimens with dentaries abruptly converging towards the mandibular symphysis and with bony tooth plates on the basihyal (i.e., rough tongue). Examination of all syntypes of $\mathrm{H}$. microlepis showed that they also have the dentaries abruptly converging towards the mandibular symphysis and a rough tongue. Hence, $H$. microlepis clearly belongs to the $H$. malabaricus species group. Syntypes of a third nominal species, H. teres from Lago Maracaibo, Venezuela, also have the dentaries abruptly converging towards the mandibular symphysis (M. Toledo-Piza, pers. com.). Although we do not have the information whether $H$. teres has bony tooth plates on the basihyal, the form of the dentaries in this species is typical of that of the $H$. malabaricus species group, a condition clearly different from the parallel dentaries present in all remaining species of Hoplias (i.e., H. lacerdae species group and $H$. aimara) as well as in the other two genera of the Erythrinidae (i.e., Erythrinus and Hoplerythrinus). More studies are needed, however, to clarify the identity of $H$. teres within the $H$. malabaricus species group and to find putative diagnostic characters for the species.

Günther (1864) described Macrodon microlepis based on seven specimens, three from "Chagres River" and four from "West Ecuador", all deposited in the Natural History Museum,
London. As a diagnostic feature, Günther (1864) mentioned the presence of 11 scales around the dorsal margin of the caudal peduncle between contralateral lateral lines. Günther (1864) did not make reference to any of the seven specimens being the holotype of M. microlepis, and thus all of them are syntypes of the species. Following the article 74 of the International Code of Zoological Nomenclature (ICZN, 1999), we herein designate one of the specimens as the lectotype (BMNH 1864.1.26.221) (Fig. 1), and the remaining six specimens are designated as paralectotypes (BMNH.1860.6.16.128, BMNH.1860.6.16.154-155, BMNH 1864.1.26.222, BMNH 1864.1.26.309) (Fig. 2). Oyakawa (2003:240) cited three lots of syntypes of $\mathrm{H}$. microlepis, but examination of all syntypes deposited at the Natural History Museum, London, revealed that two of the numbers cited by Oyakawa (2003) (BMNH 1860.6.16.154-55 and BMNH 1860.6.18.21-22) were at the same jar with three specimens. Apparently an error occurred when this lot was catalogued, and as a curatorial procedure to amend this, it was chosen the number BMNH 1860.6.16.15455 for this lot, with the other number (BMNH 1860.18.21-22) unutilized (J. MacLaine, pers. com.). In addition, we also list three additional lots of syntypes not mentioned by Oyakawa (2003) and corrected the number of specimens of each lot.

Steindachner $(1874 ; 1880)$ mentioned two species of Macrodon in Central America: M. trahira and M. microlepis, the latter considered a subspecies of $M$. trahira in his 1880 publication. He listed the same diagnostic character for $M$. microlepis as proposed by Günther (1864) (i.e., the relatively high number of scales around the dorsal portion of the caudal peduncle between lateral lines) emphasizing that this was the only difference he could find between both forms (Steindachner, 1880:49). Eigenmann \& Eigenmann (1889) considered two valid species in Macrodon: M. microlepis with 11 series of scales between lateral lines on the dorsal portion of the caudal peduncle and 43-44 lateral lines scales, and M. malabaricus with nine series of scales between lateral lines on the dorsal portion of the caudal peduncle and 39-43 lateral line scales. Although both characters might be useful in the identification of $H$. microlepis within the geographic distribution of the species, as mentioned by Eigenmann \& Eigenmann (1889), we point out that the count of lateral-line scales in Hoplias malabaricus from other localities (e.g., a few forms of $H$. malabaricus from the La Plata basin; Bifi, 2013) greatly overlaps that of $H$. microlepis, and its use should be done with caution. In addition, the number of lateral-line scales of $H$. australis, $H$. intermedius, and $H$. lacerdae, all from the $H$. lacerdae species group, also overlaps that of $H$. microlepis (Oyakawa \& Mattox, 2009). The number of scales around the caudal peduncle, on the other hand, does not overlap between $H$. microlepis and $H$. malabaricus and hence constitutes the only meristic character truly diagnostic for $\mathrm{H}$. microlepis among other species of Hoplias. 
Gill (1903) proposed a new name, Hoplias, to include all erythrinids previously classified in Macrodon, since the latter genus was preoccupied in the Sciaenidae. Starks (1906) was the first author to use the new combination for Hoplias microlepis, an act followed by subsequent auhors (e.g., Regan, 1908, Meek \& Hildebrand, 1916, Eigenmann, 1921).

Hubbs (1953) made a few taxonomic considerations regarding Hoplias microlepis. In the heading of the section concerning this species, he erroneously cited the year of publication as 1860 instead of 1864. Although Günther (1864) in the original description of $H$. microlepis mentioned the species as occurring in Guatemala, Hubbs (1953) correctly stated that this was in error since Günther (1864) only examined the syntypes from Western Ecuador and Chagres River, Panama. In addition, Hubbs (1953) selected Chagres River as the type locality of $\mathrm{H}$. microlepis, probably due to the better condition of specimens from this locality among all seven syntypes (Figs. 1-2). However, as Hubbs (1953) did no designate a lectotype, his act is not valid and the type locality should encompass the localities of all syntypes together (Article 76 of ICZN, 1999). Nevertheless, among the syntypes, specimens from Chagres River are indeed the best ones in overall condition and we herein selected one of them as the lectotype, which establishes Chagres River, Panama as the type locality.

Hoplias microlepis has an intriguing disjoint distribution in trans-Andean South America, already mentioned by Eigenmann (1921: 507-508). It is so far known only from the Guayas drainage in Ecuador and its surroundings (i.e., río Tumbes, Northwestern Peru) and from the Pacific coast of Panama and Southwestern Costa Rica, leaving a large gap along the entire coast of Colombia (Fig. 4). There are a few species of freshwater fishes occurring in the Pacific slope from Panama to Equador (e.g., Creagrutus affinis Steindachner, Roeboides occidentalis Meek \& Hildebrand, Sciades dowii (Gill)), a similar distribution to that of H. microlepis. However, all these species are also known from the Pacific slope of Colombia, a region where H. microlepis is apparently absent and substituted by H. malabaricus (e.g., Eigenmann, 1921: 508). There is a relatively small number of lots of Hoplias from the Pacific slope of Colombia, but interestingly, all specimens from coastal rivers of this region previously identified as $H$. microlepis that we had access to actually belong to Hoplias malabaricus (e.g., FMNH 50596, five specimens from río Pizarro; FMNH 56735, one specimen from río Raspadura; FMNH 56740, one specimen from río Magui). We cannot affirm that $H$. microlepis is indeed absent from the Colombian Pacific drainages, and further evidence regarding to whether the species is truly absent in the wide Pacific slope of Colombia or has just not been found yet depends on more collecting efforts in the area.

Recently, Aguirre et al. (2013) have conducted a study of $H$. microlepis in rivers and artificial impoundments along the río Guayas drainage in Ecuador and concluded that there are significant genetic divergences between populations from rivers and impoundments, also suggesting some slight morphometric variation among these populations. In the context of the putative disjoint distribution of $H$. microlepis in rivers of Panama and Ecuador, it would be interesting to perform a genetic study between these populations to determine the level of molecular divergence among them, since our meristic and morphometric data greatly overlap in samples from these two countries. In addition, records of $H$. microlepis from the Atlantic slope of Panama are restricted to the Canal Zone and are contemporary to the construction of the Panama Canal in 1911-1912 (e.g., Meek \& Hildebrand, 1916: 305), suggesting a dispersion through the canal.

\section{Acknowledgments}

This work used space and facilities of the Museu de Zoologia da Universidade de São Paulo, Núcleo de Pesquisas em Limnologia Ictiologia e Aquicultura da Universidade Estadual de Maringá, National Museum of Natural History, Washington D.C. and Natural History Museum, London. Richard P. Vari granted access to the USNM collection to AGB, and Ralf Britz, Oliver Crimmen and James MacLaine granted access to the BMNH collection to GMTM. Sandra Raredon aided with radiographs of specimens, and James MacLaine provided the photographs of the type specimens, which are copyrighted by the NHM, London. Mônica ToledoPiza kindly shared photographs of syntypes of Hoplias teres examined by her at the MNHN, Paris. Susan Mochel kindly checked the identification and counts of scales around the caudal peduncle of specimens from the FMNH collection, confirming its identification as Hoplias malabaricus. Part of the data presented herein was an excerpt of a Ph.D. Dissertation submitted by AGB as partial fulfillment of a Doctoral degree at Universidade Estadual de Maringá, under the supervision of Carla S. Pavanelli. GMTM was supported by a postdoctoral fellowship (FAPESP Proc. 2010/509418 ) and an international internship grant (FAPESP Proc. 2012/01075-1). AGB was supported by a doctoral fellowship (CAPES) and an international internship grant (CAPES Proc. 2012/8819-11-4). OTO acknowledges support from Projeto Saci - South American Characiformes Inventory (FAPESP proc. no. 2011/50282-7, http://www.projeto-saci.com).

\section{Literature Cited}

Aguirre, W. E., V. R. Shervette, R. Navarrete, P. Calle \& S. Agorastos. 2013. Morphological and genetic divergence of Hoplias microlepis (Characiformes: Erythrinidae) in rivers and artificial impoundments of Western Ecuador. Copeia, 2013: 312-323.

Barriga, R. 1991. Peces de agua dulce. Revista Politécnica, 16: 7-88. Barriga, R. 2012a. Lista de peces de agua dulce e intermareales del 
Ecuador. Revista Politécnica, 30: 83-119.

Barriga, R. 2012b. Peces. Pp. 210-215. In: Albuja, L., A. Almendáriz, R. Barriga, D. Montalvo, F. Cáceres \& J. L. Román. Fauna de vertebrados del Ecuador. Quito, Escuela Politécnica Nacional, Instituto de Ciencias Biologicas.

Bertollo, L. A. C., G. G. Born, J. A. Dergam, A. S. Fenocchio \& O. Moreira-Filho. 2000. A biodiversity approach in the neotropical fish Hoplias malabaricus. Karyotypic survey, geographic distribution of cytotypes and cytotaxonomic considerations. Chromosome Research, 8: 603-613.

Bertollo, L. A. C., M. S. Fontes, A. S. Fenocchio \& J. Cano. 1997. The $\mathrm{X} 1 \mathrm{X} 2 \mathrm{Y}$ sex chromosome system in the fish Hoplias malabaricus. I. G-, C- and chromosome replication banding. Chromosome Research, 5: 493-499.

Bertollo, L. A. C., O. Moreira-Filho \& P. M. Galetti Jr. 1986. Cytogenetics and taxonomy considerations based on chromosome studies of freshwater fish. Journal of Fish Biology, 28: 153-159.

Bifi, A. G. 2013. Revisão taxonômica das espécies do grupo Hoplias malabaricus (Bloch, 1794) (Characiformes: Erythrinidae) da bacia do rio da Prata. Unpublished Ph.D. Dissertation, Universidade Estadual de Maringá, Paraná, 51p. Avaliable from: http://nou-rau.uem.br/nou-rau/document/?code=vtls000205331 (28 Aug 2013).

Blanco, D. R., R. L. Lui, L. A. C. Bertollo, V. P. Margarido \& O. Moreira-Filho. 2010. Karyotypic diversity between allopatric populations of the group Hoplias malabaricus (Characiformes: Erythrinidae): evolutionary and biogeographic considerations. Neotropical Ichthyology, 8: 361-368.

Blanco, D. R., R. L. Lui, M. R. Vicari, L. A. C. Bertollo \& O. MoreiraFilho. 2011. Comparative cytogenetics of giant trahiras Hoplias aimara and $H$. intermedius (Characiformes, Erythrinidae): Chromosomal characteristics of minor and major ribosomal DNA and cross-species repetitive centromeric sequences mapping differ among morphologically identical karyotypes. Cytogenetic and Genome Research, 132: 71-78.

Born, G. G. \& L. A. C. Bertollo. 2001. Comparative cytogenetics among allopatric populations of the fish Hoplias malabaricus. Cytotypes with $2 \mathrm{n}=42$ chromosomes. Genetica, 110: 1-9.

Born, G. G. \& L. A. C. Bertollo. 2006. A new sympatric region for distinct karyotypic forms of Hoplias malabaricus (Pisces, Erythrinidae). Brazilian Journal of Biology, 66: 205-210.

Bussing, W. A. 1966. New species and new records of Costa Rican freshwater fishes with a tentative list of species. Revista de Biología Tropical, 14:205-249.

Cioffi, M. B. \& L. A. C. Bertollo. 2010. Initial steps in XY chromosome differentiation in Hoplias malabaricus and the origin of an X1X2Y sex chromosome system in this fish group. Heredity, 105: 554-561.

Cioffi, M. B., E. Kejnovsky \& L. A. C. Bertollo. 2011a. The chromosomal distribution of microsatellite repeats in the genome of the wolf fish Hoplias malabaricus, focusing on the sex chromosomes. Cytogenetic and Genome Research, 132: 289-296.

Cioffi, M. B., T. Liehr, V. Trifonov, W. F. Molina \& L. A. C. Bertollo. In press. Independent sex chromosome evolution in lower vertebrates: a molecular cytogenetic overview in the Erythrinidae fish family. Cytogenetic and Genome Research.

Cioffi, M. B., C. Martins \& L. A. C. Bertollo. 2009a. Comparative chromosome mapping of repetitive sequences. Implications for genomic evolution in the fish, Hoplias malabaricus. BMC Genetics, 10: 34-45.

Cioffi, M. B., C. Martins, L. Centofante, U. Jacobina \& L.A.C. Bertollo. 2009b. Chromosomal variability among allopatric populations of Erythrinidae fish Hoplias malabaricus: Mapping of three classes of repetitive DNAs. Cytogenetic and Genome Research, 125: 132-141.

Cioffi, M. B., W. F. Molina, R. F. Artoni \& L. A. C. Bertollo. 2012. Chromosomes as tools for discovering biodiversity - the case of Erythrinidae fish family. Pp. 125-146. In: Tirunilai, P. (Org.). Recent trends in cytogenetic studies - methodologies and applications. Rijeka, InTech.

Cioffi, M. B., W. F. Molina, O. Moreira-Filho \& L.A.C. Bertollo. 2011b. Chromosomal distribution of repetitive DNA sequences highlights the independent differentiation of multiple sex chromosomes in two closely related fish species. Cytogenetic and Genome Research, 134: 295-302.

Cioffi, M. B., A. Sánchez, J. A. Marchal, N. Kosyakova, T. Liehr, V. Trifonov \& L. A. C. Bertollo. 2011c. Cross-species chromosome painting tracks the independent origin of multiple sex chromosomes in two cofamiliar Erythrinidae fishes. BMC Evolutionary Biology, 11: 186-193.

Cioffi, M. B., A. Sánchez, J. A. Marchal, N. Kosyakova, T. Liehr, V. Trifonov \& L. A. C. Bertollo. 2011d. Whole chromosome painting reveals independent origin of sex chromosomes in closely related forms of a fish species. Genetica, 139: 1065-1072.

Dergam, J. A. \& L. A. C. Bertollo. 1990. Karyotypic diversification in Hoplias malabaricus (Osteichthyes, Erythrinidae) of São Francisco and Alto Paraná basins, Brazil. Brazilian Journal of Genetics, 13: 755-766.

Eigenmann, C. H. 1921. The Nature and Origin of the Fishes of the Pacific Slope of Ecuador, Peru and Chili. Proceedings of the American Philosophical Society, 60: 503-523.

Eigenmann, C. H. 1922. The fishes of western South America, Part I. The fresh-water fishes of northwestern South America, including Colombia, Panama, and the Pacific slopes of Ecuador and Peru, together with an appendix upon the fishes of the Rio Meta in Colombia. Memoirs of the Carnegie Museum, 9: 1-346.

Eigenmann, C. H. \& R. S. Eigenmann. 1889. A review of the Erythrininae. Proceedings of the California Academy of Science, 2: 100-117.

Ferraris Jr., C. J. 2007. Checklist of the catfishes, recent and fossil (Osteichthyes: Siluriformes), and a catalogue of siluriform primary types. Zootaxa, 1418: 1-628.

Fink, W. L. \& S. H. Weitzman. 1974. The so-called cheirodontin fishes of Central America with descriptions of two new species (Pisces: Characidae). Smithsonian Contributions to Zoology, 172: 1-46.

Géry, J. 1977. Characoids of the World. New Jersey, T. F. H. Publications.

Gill, T. 1903. A new name (Hoplias) for the genus Macrodon. Proceedings of the Biological Society of Washington, 16: 49-52.

Günther, A. 1864. Characinidae. Pp. 278-380. In: Günther, A. Catalogue of the fishes in the British Museum, vol. 5. Catalogue of the Physostomi, containing the families Siluridae, Characinidae, Haplochitonidae, Sternoptychidae, Scopelidae, Stomiatidae in the collection of the British Museum. London, Trustees.

Hildebrand, S. F. 1938. A new catalogue of the fresh-water fishes of Panama. Field Museum of Natural History. Publications, 22: 215-359.

Hubbs, C. L. 1953. Geographic and systematic status of fishes described by Kner and Steindachner in 1863 and 1865 from fresh waters of Panamá and Ecuador. Copeia, 1953: 141-148.

ICZN [International Commission on Zoological Nomenclature]. 1999. International Code of Zoological Nomenclature. Fourth Edition. London, International Trust for Zoological Nomenclature. 
Marques, D. F., F. A. Santos, S. S. Silva, I. Sampaio \& L. R. R. Rodrigues. 2013. Cytogenetic and DNA barcoding reveals high divergence within the trahira, Hoplias malabaricus (Characiformes: Erythrinidae) from the lower Amazon River. Neotropical Ichthyology, 11: 459-466.

Mattox, G. M. T., M. Toledo-Piza \& O. T. Oyakawa. 2006. Taxonomic study of Hoplias aimara (Valenciennes, 1846) and Hoplias macrophthalmus (Pellegrin, 1907) (Ostariophysi, Characiformes, Erythrinidae). Copeia, 2006: 516-528.

Meek, S. E. \& S. F. Hildebrand. 1916. The fishes of fresh waters of Panama. Field Museum of Natural History, Zoology, 10: 215-374.

Ortega, H., M. Hidalgo, E. Correa, J. Espino, L. Chocano, G. Trevejo, V. Meza, A. M. Cortijo \& R. Quispe. 2011. Lista anotada de los peces de aguas continentales del Perú: estado actual del conocimento, distribución, usos y aspectos de conservación. Lima, Ministerio del Ambiente, Dirección General de Diversidad Biológica - Museo de Historia Natural, UNMSM.

Ortega, H. \& R. P. Vari. 1986. Annotated checklist of the freshwater fishes of Peru. Smithsonian Contributions to Zoology, 437:, 1-25.

Oyakawa, O. T. 1990. Revisão sistemática das espécies do gênero Hoplias (grupo lacerdae) da Amazônia brasileira e região leste do Brasil (Teleostei: Erythrinidae). Unpublished MS.c. Dissertation, Universidade de São Paulo, São Paulo, 114p.

Oyakawa, O. T. 2003. Family Erythrinidae. Pp. 238-240. In: Reis, R. E., S. O. Kullander \& C. J. Ferraris Jr. (Orgs.). Check list of the freshwater fishes of South and Central America. Porto Alegre, Edipucrs.

Oyakawa, O. T. \& G. M. T Mattox. 2009. Revision of the Neotropical trahiras of the Hoplias lacerdae species-group (Ostariophysi: Characiformes: Erythrinidae) with descriptions of two new species. Neotropical Ichthyology, 7: 117-140.

Regan, C. T. 1908. Biologia Centrali-Americana: Pisces. London.

Roberts, T. 1969. Osteology and relationships of characoid fishes, particularly the genera Hepsetus, Salminus, Hoplias, Ctenolucius, and Acestrorhynchus. Proceedings of the California Academy of Sciences, 35: 391-500.

Rosa, R., M. Caetano-Filho, O. A. Shibatta \& L. Giuliano-Caetano. 2009. Cytotaxonomy in distinct populations of Hoplias aff. malabaricus (Characiformes, Erythrinidae) from lower Paranapanema River basin. Journal of Fish Biology, 75: 2682-2694.
Santos, U., C. M. Völcker, F. A. Belei, M. B. Cioffi, L. A. C. Bertollo, S. R. Paiva \& J. A. Dergam. 2009. Molecular and karyotypic phylogeography in the Neotropical Hoplias malabaricus (Erythrinidae) fish in eastern Brazil. Journal of Fish Biology, 75: 2326-2343.

Starks, E. C. 1906. On a collection of fishes made by P. O. Simons in Ecuador and Peru. Proceedings of the United States National Museum, 30: 761-800.

Steindachner, F. 1874. Die Süsswasserfische des südöstlichen Brasilien (I). Sitzungsberichte der Kaiserliche Akademie der Wissenschaften, Wien, Mathematisch-naturwissenschaftlichen Classe, 69: 1-40.

Steindachner, F. 1880. Zur Fisch-Fauna des Cauca und der Flüsse bei Guayaquil. Denkschriften der Kaiserlichen Akademie der Wissenschaften in Wien, Mathematisch-Naturwissenschaftliche Classe. 42: 55-104.

Weitzman, S. H. 1962. The osteology of Brycon meeki, a generalized characid fish, with an osteological definition of the family. Stanford Ichthyological Bulletin, 8: 1-75.

Submitted September 30, 2013

Accepted January 20, 2014 by Luiz R. Malabarba

Published June 30, 2014 